\title{
No Time For Reading, Addicted To Scrolling: The Relationship Between Smartphone Addiction And Reading Attitudes of Turkish Youth
}

\author{
Kaydırma Bağımlısıyız, Okuyacak Zaman Yok: \\ Türk Gençlerinin Akıllı Telefon Bağımlılı̆ı Ile Okumaya Yönelik Tutumları Arasındaki \\ ilişki
}

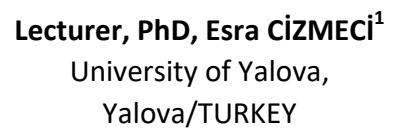

\begin{abstract}
The concept of "leisure time" originally refers to times that one does not work, but mentally improves themselves. Reading, is the primary activity that helps people to improve themselves in this way. However, today, most of the youth see reading books as a tiring activity to do, and it is an undeniable fact that, especially young peoples' leisure times are occupied by smartphone technology which provides them many facilities of entertainment. Accordingly, this study aims to search if there is a relationship between addictive smartphone usage and book reading attitudes of Turkish youth. Through implementing the survey method on 344 young participants, this study found that although females seem to have more positive attitudes towards book reading, smartphone addiction of youth does not reveal a difference in terms of gender or education level. More importantly, it is found in this study that addictive smartphone use has a negative impact on book reading attitudes of Turkish youth in general. This finding is significant considering the essentiality of reading books for youth, and decreasing rates of extra-curricular or off work book reading around the world.
\end{abstract}

Keywords: Book reading attitude, Smartphone addiction, Leisure time, Youth

Özet: "Serbest zaman" kavramı köken olarak; kişinin çalışmadığı, ancak zihinsel olarak kendini geliştirdiği zamanlara tekabül eder. Okumak, kişinin kendini bu anlamda geliştirmesini sağlayan birincil etkinliktir. Ne yazık ki, günümüzde okumak, gençler tarafından yorucu bir aktivite olarak görülmektedir ve günümüz gençliğinin serbest zamanlarıın çoğunun, kendilerine birçok eğlence imkânı sunan akıllı telefonlar tarafından meşgul edildiği de inkâr edilemez bir gerçektir. Bununla bağlantılı olarak, bu çalışmada Türk gençlerinin okumaya yönelik tutumları ile bağımlıık düzeyinde akıllı telefon kullanımları arasında bir bağlantı olup olmadığını tespit etmek amaçlanmıştır. 344 genç birey üzerinde uygulanan anketler sonucunda, kadın katılımcıların çoğunun erkek katılımcılara oranla okumaya yönelik daha pozitif bir tutum içerisinde olduğu bulgulansa da, bağımlıık düzeyinde akıllı telefon kullanımının cinsiyet ya da eğitim seviyesi gözetmeksizin gençler arasında yaygın olduğu tespit edilmiştir. Dahası, akılı telefon bağımlıı̆ının,

\footnotetext{
${ }^{1}$ esra.cizmeci@yalova.edu.tr
} 
Türkiye'deki gençlerin okumaya yönelik tutumları üzerinde genel olarak olumsuz bir etki oluşturduğu bulgulanmıştır. Bu bulgu, okumanın gençler açısından elzem olması ve dünya genelinde serbest zamanda kitap okuma oranlarının azaldığı gerçekleri göz önüne alındığında büyük önem taşımaktadır.

Anahtar Kelimeler: Okumaya yönelik tutum, Akıllı telefon bağımlılı̆ı, Serbest zaman, Gençlik

\section{Introduction}

Reading books is an essential activity for a person's self-development. It provides us the ability to critically look at and understand people and the world around us. It helps people to be creative, productive, able to use information and to continuously improve themselves. In definition, reading is basically "the ability to recognize, and examine words or sentences, and understand the information within" (Lone, 2011).

Reading books improves one's thinking by giving them new concepts and ideas and broaden their worldview. It also develops one's language and vocabulary, affects the level of comprehension and understanding, and so enhances their communication skills. Moreover, reading books stimulates the imagination and gives one the power of insight, as well as enhancing emotional intelligence, evoking empathy and providing characters that one may identify themselves with (Johnsson-Smaragdi and Jönsson, 2006: 521). Relatedly, reading books in leisure times has impact on both biological and psychological development of a person. For example, there are big differences between reading a novel, and watching that as a movie. Watching is passive, whereas one has to work their brain and imagination while reading a book (Turkyilmaz, 2012: 478).

Beside all afore-mentioned benefits that reading books provides to a person, the number of people who prefer reading books in their leisure time seems to decrease all around the world. The advent of new media technologies like the Internet, social media and smartphones led to the occupation of leisure times with these technologies. Especially smartphones are accused of holding most of a person's time, because they include all media within themselves through the Internet and their applications, anywhere and anytime to gratify any kind of needs.

Because they are the future of societies, reading books in leisure times is significant especially for young people's self-development, and more importantly, young people are found to be the most addictive users of smartphones. In this significance, this study aims to find if young people's addictive smartphone use has any impact on their attitudes towards reading books in leisure times.

\section{Literature Review}

\subsection{Book reading and Technology Use}

Leisure times are the times in which an individual is free of any obligatory duties in daily life like working, running errands for life maintenance, and etc. In its roots, the word "leisure" comes from the Latin word "licere", which means "to be free". So originally, back in the ancient periods, leisure times were those free times in which an individual needed to critically think and question themselves and the social reality (Aydogan, 2000: 15-21). By providing the ability to expand one's worldview and critical thinking, book reading is an activity that serves to this original meaning of leisure. Relatedly, when book reading rates decrease in a society, beside individual development, also social development of that society eventually gets damaged.

As capitalism took rule around the world, the original meaning of leisure time was transformed into consuming and so serving the system when one is not working. Today's leisure time cannot be thought separate from communication devices (Giddens, 2010: 40). Oskay (2013:148, 416) claimed that these 
devices prevent individuals from critical thinking and turn them into "idiots". At this point, the significance of book reading in leisure times in terms of raising awareness comes forward. Especially for the personal development of young people, who are the source of future social development, reading books is an essential activity.

However, as media technologies developed, tools provided for leisure time activities increased and so the quality of leisure times changed. Spending more time with media use automatically decreases time left for reading a book. With the invasion of television, radio, computers, the Internet and new media technologies like tablets and smartphones, media use has become the primary leisure time activity. Most importantly, individuals left some of their good old habits like reading books, and developed new ones (Aksaçlıoğlu and Yılmaz, 2007: 5).

In line with the significance of reading books for youth, many studies tried to measure young people's attitudes towards book reading. Findings of Nestle Family Monitor (2003) demonstrated that, young girls were more enthusiastic about reading books than young boys. The research also found that reading books in bed before sleep at night was the usual time for youth to read. Young participants of this research mostly had positive attitudes towards book reading, however only $16 \%$ of the older youth thought that reading a book improved their life, whereas younger participants found book reading as 'boring'. More importantly, seven in ten of all participants declared that they would prefer watching television or a DVD/video than reading a book, whereas over half of the participants said that they would prefer to use the Internet than reading a book.

Similarly, Hughes-Hassel and Rodge (2007: 23-27) conducted a research in US and found that $72 \%$ of their 1,340 young participants declared that they do engage in book reading as a leisure activity. However, further details of the study revealed that they did not read for leisure much in summer (only $15 \%$ of males and $20 \%$ of girls), because most of their leisure book reading was to get rewarded by the school (by the reading incentive program). More importantly, it was found that the most preferred reading material by these young people were found to be popular magazines, not literary books. In line with that, $46 \%$ of the participants declared that although they read in their leisure times to relieve boredom; watching television, surfing the Web, or playing video games were more preferrable activities for them in leisure times rather than reading books.

Looking for a similar problematic years ago, Koolstra and Van Der Voort (1996: 26) found that frequent television viewing was from one of the factors that reduced children's leisure-time book reading. Moreover, Broddason (2006: 112) suggested in his study on Icelanders who consider themselves to be 'bookish', that as television and the Internet entered homes, book reading in leisure times has declined among teens. Differently, Johnsson-Smaragdi and Jönsson (2006: 538) found in their research that time spent on ICT use do not have any affect on young people's book reading habits. Accordingly, they suggested that many young people associated leisure book reading with school, demands of adults, and achievements, and that might be why leisure book reading was low among youth.

There are also studies from Turkey which investigates young people's use of media technologies and book reading habits in leisure time. A research by Esgin and Karadag (2000: 21) conducted on Turkish college students in $\mathbf{2 0 0 0}$ found that only $5 \%$ of the students spent their leisure times at libraries, and those who read books for leisure were only 26\%. Later, Aksaçlıoğlu and Yılmaz (2007: 10) studied the impact of television viewing on reading habits, and claimed that television provides individuals a new lifestyle that is mostly visual and does not require reading books much. To be able to keep the viewer's attention, images and sounds continuously change on television, which prevents viewers from concentrating on anything for 
long. As minds get lazy after watching television, reading a book becomes a hard and unattractive activity for people.

Aksaçlıoğlu and Yılmaz (2007: 23) found that as leisure time activities, watching television and using a computer come first for children, whereas reading a book is the final choice. Ten years ago, primary school students admitted the fact that they spent more time on watching television and using a computer as the reason for not reading books much. Oppositely, $\operatorname{Kır}(2007$ : 320) found that college students mostly (44.4 \%) read books, magazines, or newspapers in their leisure times, whereas they preferred watching television less (10.3\%).

Among all communication technologies, smartphones come first as the main tool of young people's leisure today. Relatedly, by using the concept of "mobile leisure (m-leisure)" (Kaya and Argan, 2015: 23) in their study; Kaya and Argan (2015: 29) found in their in depth interviews with Turkish college students that especially mobile phones make young people relax, increase their personal freedom, relieve boredom, make solitude an leisure more enjoyable, and more meaningful.

Mobile phones that provide their users almost all kinds of leisure activities are "smartphones". With all those facilities they provide, smartphones invaded especially young people's lives so much that their use may prevent other activities in daily lives and easily turn into addiction.

\subsection{Smartphone Addiction}

Lepp (2014: 381) names smartphone as the "modern cell phone", because it functions as an "internetconnected computer". In relation to that, in this study mobile phones that provide their users almost anything they search for in their leisure times will be called under the name of "smartphones". Smartphones provide their users many functions like the Internet, games, and other entertaining applications, besides basic communication, and their main target are young people (Al-Barashdi et al., 2015: 211). Bian and Leung (2015: 73) suggest that because smartphones let users to connect to the Internet and engage in various activities like searching engines, watching videos, checking social media, playing games and etc. anytime and anywhere, users may easily get addicted to them by preoccupation and not regarding any harmful consequences.

Al-Barashdi et al. (2015: 211) define "smartphone addiction" as using smartphones so heavily that one neglects other areas of their life. Shambare et al. (2012: 573) described mobile phone addiction as the biggest non-drug addiction of the 21st century, and suggested that young people are the main actors of this addiction. In line with this, studies (Bianchi \& Phillips, 2005) tell us that mostly young people reveal problematic smartphone use. For instance, Balakrishnan and Raj (2012: 270) found that Malaysian youth are extremely attached and so addicted to their mobile phones.

There are many studies looking for the reasons of mobile phone, cell phone and smartphone addiction. Bianchi \& Phillips (2005: 49) found that young people, and also those who have personal traits of extraversion and low self-esteem tend to be more addicts of mobile phones. Some studies (Zulkefly, 2009: 206; Rice \& Katz, 2003: 618) found that when the family income is high, youth spend more time on mobile phone use. On the other hand, other studies (Brown et al., 2011: 152) found that young individuals with lower family income use their mobile devices more, both because they want to compensate their economic status, and because these devices are the only tools that they can access the Internet. Chiu (2014: 55) found that interpersonal relationship stress has the highest influence on university students' smartphone addiction. Similarly, Samaha and Hawi (2016: 324) found that perceived stress and smartphone addiction are highly related to each other. Kim et al. (2015: 4-5) claim that personal characteristics of the user can 
predict smartphone addiction. They found that psychosocial factors such as depression and aggression are highly related with smartphone addiction, and men are more addicted to their smartphones than women. Bianchi and Phillips (2005: 49) also found that males are more addictive smartphone users. On the other hand, some other studies (Balakrishnan \& Raj, 2012: 270) found that females use their phones more addictively, and mostly to socialize, express their emotions and for safety.

Although on their research on Chinese youth, Bian and Leung (2015: 73-74) found that psychological characteristics of loneliness and shyness are powerful predictors of smartphone addiction, more importantly, they also found that smartphone usage habits like excessive use for information seeking or fun seeking also have high impact on getting addicted. Ahn et al. (2014: 13-14) found that smartphone addicts use social and communication applications more frequently than game applications and non-addicted users use their smartphones more in the afternoon, addicts make their usage at night more. Lemola et al. (2015: 414-415) also found and focused on the fact that adolescents who own a smartphone tend to use these devices a lot at night before sleep. Here, it must be pointed out that before the advent of these technologies, book reading was a usual activity to do before sleep.

More importantly, Zhang et al. (2014) found in their research on Chinese youth that the strongest motives that reinforce smartphone addiction are pastime, and perceived enjoyment, which clearly shows that these young people mostly prefer smartphone usage in their leisure times. Research of Haug et al. (2015: 304) on the youth of Switzerland found that social networking is the main factor of smartphone addiction. By focusing on the device characteristics and the content used, Jeong et al. (2016: 14-15) found that social networking sites lead to smartphone addiction more than games, because games are harder to play on small screens, whereas social networking sites function quite practically on smartphones.

Moreover, Lepp et al. (2015: 210) claim that for college students, smartphones are designed primarily for entertainment purposes. Lepp (2014: 387-388) found in his study that young people who are high frequency cell phone users relate cell phone use with leisure that is enjoyable, relaxing, freely chosen, and intrinsically motivated. Lepp et al. (2015: 217) suggest through their research that individuals who enjoy effortful thinking use smartphones less in their leisure times, and such individuals experience more satisfactory leisure. These findings directly relate to the current study, because book reading is a leisure activity that requires effortful thinking, therefore if we find high smartphone addiction, than book reading attitude must be negative.

In terms of understanding the relationship of Turkish youth with their smartphones, Bulduklu and Ozer (2016: 2983) similarly found that Turkish youth use their smartphones to socialize, to access information, to adapt to technological developments, for fun, for the fact that they facilitate daily life, and for safety. Some participants of this research are also aware of the facts that smartphones cause loss of time and they are harmful for health, whereas $7,4 \%$ of the participants think that smartphone use brings no harm at all. Most see the benefit of using smartphones as providing traditional communication functions, which shows that communicating with others (through social media, calling, texting, etc.) and therefore socializing are main motivations for Turkish youth to use smartphones.

In line with all the literature mentioned above, this study aims to look at whether there is an impact of smartphone addiction on the book reading attitudes of young people, or not. Relatedly, the hypothesis of this study is that since frequent smartphone use turns into an addiction and takes most of the time of young people, they will not be able to find much time or will to read books in their leisure times, so their book reading attitude will be negative. 


\section{Method}

Kwon et al. (2013) developed a 33-item scale to measure smartphone addiction at first place, but they had undesired results and created this 10-item short version out of that initial scale. Demirci et al. (2014) measured and confirmed the validity and reliability of the Short Addiction Scale in terms of Turkish participants. It is a short, multiple-choice, easily understandable, applicable and rateable scale.

Items in the Short Addiction Scale generally try to measure if smartphone use has a negative impact on one's daily life or not, via questions such as "Missing planned work due to smartphone use", or "Feeling impatient and fretful when I am not holding my smartphone", or "Using my smartphone longer than I had intended". More importantly, items in the scale appeal to young individuals who frequently use smartphones and social networking (Demirci et al., 2014: 231).

The Reading Attitudes Scale, on the other hand, has been developed by Gömleksiz (2004), appealing to Turkish college students. Initially it was developed as a 60 items scale, which was reduced to 30 items consisting of 21 positive and 9 negative items after the pilot study on college students. Items in the Reading Attitude Scale generally try to measure whether participants like reading books or not, and whether they think reading books is a useful activity for themselves or not via questions such as, "I think reading books is boring", or "Reading books makes us understand other people and the World better", or "Reading books can enhance my vision".

This research has been implemented with both afore-mentioned scales consisting of 40 items in total, between March 2017 and May 2017 on 450 participants at the ages of 18-29. 200 surveys were filled online (surveey.com) and 250 were filled on hard copy forms. 114 of the survey forms were eliminated because of inappropriate and contradictory answers and many empty items. Eventually, 344 surveys are analyzed in total. Participants are recruited via snowball sampling from young people living in Istanbul.

The initial hypothesis of this study is that, since leisure time habits of youth has been changing especially after smartphones, addictive smartphone users will have a low reading attitude.

To determine the reliability of the scales, Cronbach's Alpha coefficient is calculated. Cronbach's Alpha coefficients are found as 0.94 for the Reading Attitude Scale, and as 0.89 for the Smartphone Addiction Scale. These calculations confirm that the internal consistency of both scales has high levels of validity and reliability.

"In analyzing data, frequency, percentage variance, averages and standart deviation are calculated. Moreover, to obtain the relational situation among reading attitudes and smartphone addiction, Pearson correlation and regression analyses are ran. Findings are evaluated in $95 \%$ reliability and $5 \%$ meaningfulness levels.

"Furthermore, in comparing two independent groups, T-Test is ran for independent samples, whereas oneway variance analysis (ANOVA) is used in comparing two or more independent groups. Following the oneway variance analysis, LSD Test is ran as a supplement to determine differences.

\section{Results}

Below are the findings from the present research: 
Table 1: Distribution of Demographic Features

\begin{tabular}{|ll|l|l|}
\hline Variables & Groups & Frequency & Percent \\
\hline \multirow{2}{*}{ Sex } & Female & 242 & 70.3 \\
& Male & 102 & 29.7 \\
& Total & 344 & 100.0 \\
\hline \multirow{3}{*}{ Age } & $18-21$ & 210 & 61.0 \\
& $22-25$ & 110 & 32.0 \\
& $26-29$ & 24 & 7.0 \\
& Total & 344 & 100.0 \\
& High School & 21 & 6.1 \\
& Associate & 143 & 41.6 \\
& Degree & 180 & 52.3 \\
& Undergraduate & 344 & 100.0 \\
\hline
\end{tabular}

Table 1 reveals the demographic features of the participants. 242 of the participants (70,3\%) are female, whereas 102 of the participants $(29,7 \%)$ are male. 210 participants $(61,0 \%)$ are at the ages of 1821,110 participants $(32,0 \%)$ are at the ages of $22-25$, and 24 participants $(7,0 \%)$ are at the ages of 26-29. 21 participants $(6,1 \%)$ are at high school level, 143 participants $(41,6 \%)$ are at associate degree level, and 180 participants $(52,3 \%)$ are at undergraduate level in terms of education.

Table 2: Comparison of Variables In Terms of Gender

\begin{tabular}{|c|c|c|c|c|c|c|}
\hline Variables & Gender & $\mathbf{N}$ & Mean & $\begin{array}{c}\text { Std. } \\
\text { Deviation }\end{array}$ & $\mathbf{t}$ & $\mathbf{p}$ \\
\hline \multirow{2}{*}{ Reading Attitude } & Female & 242 & 3.99 & 0.62 & \multirow{2}{*}{4.65} & \multirow{2}{*}{0.00} \\
\hline & Male & 102 & 3.65 & 0.59 & & \\
\hline \multirow{2}{*}{ Smartphone Addiction } & Female & 242 & 2.89 & 0.82 & \multirow{2}{*}{-0.76} & \multirow{2}{*}{0.45} \\
\hline & Male & 102 & 2.96 & 0.83 & & \\
\hline
\end{tabular}

According to the Table 2, Reading Attitude differs statistically $(p<0.05)$ in terms of the gender of participants. As a result of the analysis, it is found that female participants have a more positive book reading attitude than male participants. On the other hand, smartphone addiction of the participants does not reveal a statistical difference in terms of gender $(p>0.05)$.

Table 3: Comparing Variables In Terms of Age Groups

\begin{tabular}{|c|c|c|c|c|c|c|c|}
\hline Variables & $\begin{array}{c}\text { Age } \\
\text { Groups }\end{array}$ & $\mathbf{N}$ & Mean & $\begin{array}{c}\text { Std. } \\
\text { Deviation }\end{array}$ & $\mathbf{F}$ & $\mathbf{p}$ & Difference \\
\hline \multirow{3}{*}{$\begin{array}{l}\text { Reading } \\
\text { Attitude }\end{array}$} & $\begin{array}{c}18-21 \\
(1)\end{array}$ & 210 & 4.03 & 0.60 & \multirow{3}{*}{16.61} & \multirow{3}{*}{0.00} & $1>2$ \\
\hline & $22-25(2)$ & 110 & 3.62 & 0.60 & & & \\
\hline & $26-29(3)$ & 24 & 3.88 & 0.71 & & & \\
\hline Smartphone & $18-21(1)$ & 210 & 2.84 & 0.89 & 4.31 & 0.01 & $2>1,2>3$ \\
\hline
\end{tabular}




\begin{tabular}{lllll} 
Addiction & $22-25(2)$ & 110 & 3.09 & 0.69 \\
& $26-29(3)$ & 24 & 2.68 & 0.69 \\
\hline
\end{tabular}

Table 3 demonstrates that, book reading attitude of the participants reveal statistical differences $(p<0.05)$ in terms of age groups. It is found that, the age group of 18-21 have more positive book reading attitudes in comparison to the age groups of 22-25. Also, smartphone addiction differs statistically $(p<0.05)$ in different age groups. Accordingly, it is found that, young participants who are 22-25 years old have higher smartphone addiction than other age groups.

Table 4: Comparing Variables In Terms of Education Levels

\begin{tabular}{|c|c|c|c|c|c|c|c|}
\hline Variables & Education Level & $\mathbf{N}$ & Mean & $\begin{array}{c}\text { Std. } \\
\text { Deviation }\end{array}$ & $\mathbf{F}$ & Sig. & Difference \\
\hline \multirow{3}{*}{$\begin{array}{l}\text { Reading } \\
\text { Attitude }\end{array}$} & High School (1) & 21 & 3.34 & 0.56 & \multirow{3}{*}{10.78} & \multirow{3}{*}{0.00} & \multirow{3}{*}{$\begin{array}{c}3>1,3>2, \\
2>1\end{array}$} \\
\hline & $\begin{array}{l}\text { Associate Degree } \\
\text { (2) }\end{array}$ & 143 & 3.85 & 0.66 & & & \\
\hline & $\begin{array}{l}\text { Undergraduate } \\
\text { (3) }\end{array}$ & 180 & 3.98 & 0.58 & & & \\
\hline \multirow{3}{*}{$\begin{array}{l}\text { Smartphone } \\
\text { Addiction }\end{array}$} & High School & 21 & 3.08 & 0.75 & \multirow{3}{*}{0.52} & \multirow{3}{*}{0.60} & \\
\hline & Associate Degree & 143 & 2.88 & 0.87 & & & \\
\hline & Undergraduate & 180 & 2.91 & 0.80 & & & \\
\hline
\end{tabular}

Table 4 shows that book reading attitude differs statistically $(p<0.05)$ in terms of the education levels of participants. Findings demonstrate that as the education level increases, positive reading attitude also increases. However, no statistical differences $(p>0.05)$ in terms of participants' education level found in their smartphone addiction.

Table 5: Descriptive Statistics About Variables

\begin{tabular}{llllll}
\hline Variables & $\mathbf{N}$ & Mean & Std. Deviation & Skewness & Kurtosis \\
Reading Attitude & 344 & 3,89 & 0,63 & $-0,37$ & $-0,68$ \\
Smartphone Addiction & 344 & 2,91 & 0,83 & $-0,12$ & $-0,09$ \\
\hline
\end{tabular}

Table 5 demonstrates that participants have high level of positive book reading attitude, and moderate level of smartphone addiction.

Table 6: Correlation Analysis

\begin{tabular}{|c|c|c|}
\hline & & Smartphone Addiction \\
\hline \multirow{3}{*}{ Reading Attitude } & Pearson Correlation &,$- 207^{* *}$ \\
\hline & Sig. (2-tailed) & , 000 \\
\hline & $\mathrm{N}$ & 344 \\
\hline
\end{tabular}


Results of the Correlation Analysis shown in Table 6 demonstrates that smartphone addiction has a negative correlation with reading attitudes.

Table 7: The Impact of Smartphone Addiction on Reading Attitudes

\begin{tabular}{|l|l|r|r|}
\hline \multirow{2}{*}{ Independent Variable } & Unstandardized Coefficients & \multirow{2}{*}{$\mathbf{t}$} & Sig. \\
\cline { 2 - 3 } & B & & \\
\hline (Constant) & 4.35 & -35.49 & .000 \\
Smartphone Addiction & -0.16 & .000 \\
\hline \multirow{2}{*}{} & $\mathrm{R}^{2}=0.043$ & & \\
& $\mathrm{~F}=15.317$ & \\
& Sig. $=0.000$ &
\end{tabular}

Dependent Variable: Reading Attitudes

According to the regression analysis results shown in Table 7, smartphone addiction has a meaningful and negative impact on reading attitudes $(~(=-0.16, t=-3.91, F=15.317, p<0.05)$. It is seen that $4,3 \%$ of the change in reading attitudes is explained by smartphone addiction $\left(R^{2}=0.043\right)$.

\section{Discussion}

Especially after the spread and frequent use of new media technologies, the worry that book reading in leisure times is decreasing, is a world-wide discussion topic. Book reading is an activity that improves one's significant abilities such as critical thinking, impressive skills of speaking, and etc. However, reading books is also an activity that forces one to think, therefore requiring a special time allocation. Smartphones on the other hand, ease many activities that one can do in their daily life. They also provide many facilities for leisure times, which require less mental effort, but more time from one's leisure times. Therefore, it was significant to search and see if addictive use of smartphones has any impact on young people's attitudes towards book reading.

There are many studies ran all around the world that look at the acitivity of reading books in an age of technology, from different perspectives. For instance, Years ago, AbdulKarim and Hasan (2007: 296) found that Malaysian university students read a lot during their leisure time. However, five years later, Balakrishnan and Raj (2012: 270) found that Malaysian youth are extremely attached and so addicted to their mobile phones. Furthermore, Huang et al. (2014: 456-458) found that college aged youth spend most of their leisure times by socializing with others through technology applications such as SNSs and generally the Internet, rather than reading books. In line with that, 2016 findings of the Turkish Statistical Institution (cnnturk.com, 21.02.2017) reveal that Turkish individuals read books only for one minute daily on average, whereas they spend six hours for watching television, and 3 hours for using the Internet.

Studies from Turkey (Can et al., 2010: 15-17; Turkyilmaz, 2012: 487-488) found that as Turkish youth gets older, their book reading habits decrease even more. Similarly, we found that, the age group of 18-21 have more positive reading attitudes in comparison to the age groups of 22-25. Also, it is found in the current study that female participants have a more positive reading attitude than male participants. This finding is consistent with other studies from both Turkey and other countries around the world. Dilshad et al. (2013: 318) found that female college students in Pakistan have more positive attitudes toward reading extracurricular books than males. Studies from Turkey (Can et al., 2010: 15-17; Arslan et al., 2009: 121-122) also found that college-aged girls have more positive attitudes towards reading books than boys, and they explain this fact with them having different emotional and developmental needs in comparison to boys. 
On the other hand, as girls seem to be more positive about reading books, boys are found to be closer to using communication technologies. In connection with this, Kim et al. (2015: 4-5) claim that men are more addicted to their smartphones than women. Bianchi and Phillips (2005: 49) also found that males are more addictive smartphone users. On the other hand, some other studies (Balakrishnan \& Raj, 2012: 270) found that females use their phones more addictively, and mostly to socialize, express their emotions and for safety. However, in the current study, interestingly no statistical differences in terms of gender are found for smartphone addiction. As Noyan et al. (2015: 79) also found, the risk of smartphone addiction seems to be high among Turkish youth in general. In line with that, we also found that smartphone addiction of the participants do not differ in terms of their education levels, although those with higher education have more positive attitudes towards reading books.

Although attitudes towards reading books may seem to be positive, it is an undeniable fact that smartphone use occupies a significant amount of young people's leisure times today. Johnsson-Smaragdi and Jönsson (2006: 538) found in their research that time spent on ICT use do not have any affect on young people's book reading habits. Can et al. (2010: 15-17) also found that time spent for watching television and using computers do not affect time spent for reading books. However, significantly, the current study found that smartphone addiction has a meaningful and negative impact on young people's reading attitude. It is found that $4,3 \%$ of the change in reading attitudes is explained by smartphone addiction. This finding can be supported by Lepp et al.'s (2015: 217) suggestion that smartphone use and effortful thinking like reading books are not activities that are in collusion with each other. Similarly, Durualp et al. (2013: 122-125) found that heavy users of the Internet do not have book reading habits. This can support our study because of the fact that the Internet is mostly used on smartphones by the youth of today.

The initial hypothesis of this study was that, since leisure time habits of youth has been changing especially after smartphones, those addictive smartphone users would have a low reading attitude. When the reasons of not reading are analzed at the basis of questions, it is seen that the participants think that there is a lack of consciousness about the significance of reading books, and most of the young people do not have book reading habits in their leisure times. On the other hand, answers about smartphone use reveal that most of the participants admit that they miss their planned work due to smartphone use, they have a hard time concentrating in class, while doing assignments, or while working due to smartphone use, and finally, they use their smartphones longer than they had intended.

When combined with all the findings discussed above, eventually, this study demonstrate that heavy use of smartphones is a significant factor that may take book reading away from the lives of young people.

\section{Limitations}

Although this is the first study in Turkey to look at the relationship between smartphone addiction and young people's attitudes towards reading books, it has some limitations. First, a longitudinal study that observes young people's leisure habits could give more vivid results in terms of seeing how much of their time is allocated to reading books, and how much to smartphone use.

Secondly, a qualitative study of in-depth interviews could give more explanatory results in terms of what young people choose to do in their leisure times and why. Or, to be able to be completely sure about if addictive smartphone use is the main reason that has impact on young people's attitudes towards reading books, further studies could add more items in their research.

And finally, because the survey in this study was an online survey, there is a possibility that those participants who use the Internet and smartphones intensely might be overrepresented at the results. 


\section{Conclusion}

The significance of reading books in any person's life cannot be disregarded. However, the invasion of smartphones in our lives is also an inevitable situation. James and Drennan (2005: 87) found that mobile phone addiction brings financial issues and emotional stress, damages relationships, and decreases literacy. Moreover, Lepp et al. (2013: 7) found that intensive cell phone use invites their users into doing sedentary activities in their leisure times as in using a computer and watching television.

Beside these harms, taking young people who are the future of societies away from reading books can bring even more harmful consequences to societies. Social media applications which is what they mostly use on their smartphones do not lead youth towards critical thinking about the world, rather, these technologies distract their attention away from the realities via entertainment which occupies a lot of time. Moreover, even if they may get information about almost anything from their smartphones, accessing the correct information is always a matter when it is about social media. Books, on the other hand, represent deeper ideas, worlds and information from certain views, and do not let much distraction. Therefore, for such reasons and more, encouraging youth to read books in leisure times that will broaden their minds and bring them a significant self-improvement is essential for the future of developed societies.

\section{References}

Abdul Karim, N.S., Hasan, A. (2007). Reading habits and attitude in the digital age. The Electronic Library, 25(3), 285-298.

Ahn, H., Wijaya, M.E., Esmero, B.C. (2014). A Systemic Smartphone Usage Pattern Analysis: Focusing on Smartphone Addiction Issue. International Journal of Multimedia and Ubiqitous Engineering, 9(6), 914. http://dx.doi.org/10.14257/ijmue.2014.9.6.02

Aksaçlıoğlu, A.G., Yılmaz, B. (2007). Impacts of Watching Television and Computer Using on Students' Reading Habits. Türk Kütüphaneciliği, 21(1), 3-28.

Al-Barashdi, H.S., Bouazza, A., Jabur, N.H. (2015). Smartphone Addiction among University Undergraduates: A Literature Review. Journal of Scientific Research \& Reports, 4(3), 210-225. DOI: 10.9734/JSRR/2015/12245

Arslan, Y., Çelik, Z., Çelik, E. (2009). Determination of University Students' Attitudes Toward Reading Habit. Pamukkale Üniversitesi Eğitim Fakültesi Dergisi, 26, 113-124.

Aydogan, F. (2000). Medya ve Serbest Zaman. Istanbul: Om Yayinevi.

Balakrishnan V, Raj RJ. Exploring the relationship between urbanized Malaysian youth and their mobile phones: A quantitative approach. Telematics and Informatics. 2012;29:263-72.

Bian, M., Leung, L. (2015). Linking Loneliness, Shyness, Smartphone Addiction Symptoms, and Patterns of Smartphone Use to Social Capital. Social Science Computer Review, 33(1), 61-79. DOI: 10.1177/0894439314528779

Bianchi A, Phillips J. Psychological predictors of problem mobile phone use. Cyber Psychology and Behavior. 2005;8(1):39-51.

Bulduklu, Y., Ozer, N.P. (2016). Young People's Smart Phone Use Motivations. Journal of the Human and Social Sciences Researches, 5(8), 2963-2986.

Broddason, T. (2006). Youth and New Media In the New Millenium. Nordicom Review, 27(2), 105-118.

Brown K, Campbell SW, Ling R. Mobile phones bridging the digital divide for teens in the US? Future Internet. 2011;144-58. DOI:10.3390/fi3020144.

Can, R., Turkyilmaz, M., Karadeniz, A. (2010). Adolescent Students' Reading Habits. Journal of Ahi Evran University Kirsehir Educational Faculty, 11(3), 1-21.

Chiu, S. (2014). The relationship between life stress and smartphone addiction on Taiwanese university student: A mediation model of learning self-Efficacy and social self-Efficacy. Computers in Human 
Behavior, 34, 49-57.

Demirci, K., Orhan, H., Demirdas, A., Akpinar, A., Sert, H. (2014). Validity and Reliability of the Turkish Version of the Smartphone Addiction Scale in a Young Population. Bulletin of Clinical Psychopharmacology, 24(3), 226-234. DOI: 10.5455/bcp.20140710040824

Dilshad, M., Adnan, A., Akram, A. (2013). Gender Differences in Reading Habits of University Students: An Evidence from Pakistan. Pakistan Journal of Social Sciences, 33(2), 311-320.

Esgin, A., Karadağ, Ö. (2000). Üniversite Öğrencilerinin Okuma Alışkanlığı. Popüler Bilim. Eylül 2000, 7(82), 19-23.

Durualp, E., Çiçekoğlu, P., Durualp, E. (2013). Examination of the Attitude of Reading Students in the 8th Grades in terms of Use Internet and Reading Habits. International Journal of Turkish Literature Culture Education, 2(1), 115-132.

Giddens, A. (2010). Modernite ve Bireysel Kimlik. Istanbul: Say Yayinlari.

Gömleksiz, M.N. (2004). Validity and Reliability of an Attitude Scale Towards Reading Habit. Fırat University Journal of Social Science, 14(2), 185-195.

Haug, S., Castro, R.P., Kwon, M., Filler, A., Kowatsch, T., Schaub, M.P. (2015). Smartphone use and smartphone addiction among young people in Switzerland. Journal of Behavioral Addictions, 4(4), 299307.

Huang, S., Capps, M., Blacklock, J., Garza, M. (2014). Reading Habits of College Students in the United States. Reading Psychology, 35(5), 437-467. DOI: 10.1080/02702711.2012.739593

Hughes-Hassel, S., Rodge, P. (2007). The leisure reading habits of urban adolescents. International Reading Association, 51(1), 22-33. doi:10.1598/JAAL.51.1.3

James D, Drenn J. Exploring addictive consumption of mobile phone. Journal of Adolescence. 2005;27(1):8796.

Jeong, S.H., Kim, H., Yum, J.Y., Hwang, Y. (2016). What type of content are smartphone users addicted to?: SNS vs. games. Computers in Human Behavior, 54, 10-17.

Johnsson-Smaragdi, U., Jönsson, A. (2006). Book Reading in Leisure Time: Long-Term changes in young people's book reading habits. Scandinavian Journal of Educational Research, 50(5), 519-540. DOI: 10.1080/00313830600953600

Kaya, S., Argan, M. (2015). An Exploratory Qualitative Study on Mobile Leisure (M-Leisure): A Case of Mobile Phone Users in Turkey. Journal of Internet Applications and Management, 6(1), 21-32. doi: 10.5505/iuyd.2015.47955

Kır, i. (2007). Leisure Activities of Higher Education Youth: KSÜ Example. Fırat University Journal of Social Science, 17(2), 307-328.

Kim, M., Kim, H., Kim, K., Ju, S., Choi, J., Yu, M. (2015). Smartphone Addiction: (Focused Depression, Aggression and Impulsion) among College Students. Indian Journal of Science and Technology, 8(25), 1-6. DOI: 10.17485/ijst/2015/v8i25/80215

Koolstra, C.M., Van Der Voort, T.H.A. (1996). Longitudinal Effects of Television on Children's Leisure-Time Reading: A test of Three Explanatory Models. Human Communication Research, 23(1), 4-35.

Kwon, M., Lee, J. Y., Won, W. Y., Park, J. W., Min, J. A., Hahn, C., ... \& Kim, D. J. (2013). Development and validation of a smartphone addiction scale (SAS). PloS one, 8(2), e56936.

Lemola, S., Perkinson-Gloor, N., Brand, S., Dewald-Kauffmann, J.F. (2015). Adolescents' Electronic Media Use at Night, Sleep Disturbance, and Depressive Symptoms in the Smartphone Age. J Youth Adolescence, 44, 405-418. DOI 10.1007/s10964-014-0176-x

Lepp, A. (2014). Exploring the relationship between cell phone use and leisure: an empirical analysis and implications for management. Managing Leisure, 19(6), 381-389. DOI: 10.1080/13606719.2014.909998 
Lepp, A., Barkley, J.E., Sanders, G.J., Rebold, M., Gates, P. (2013). The relationship between cell phone use, physical and sedentary activity, and cardiorespiratory fitness in a sample of U.S. college students. International Journal of Behavioral Nutrition and Physical Activity, 10(79), 1-9.

Lepp, A., Li, J., Barkler, J.E., Slaehi-Esfahani, S. (2015). Exploring the relationships between college students' cell phone use, personality and leisure. Computers in Human Behavior, 43, 210-219. http://dx.doi.org/10.1016/j.chb.2014.11.006

Noyan, C.O., Enez Darçın, A., Nurmedov, S., Yılmaz, O., Dilbaz, N. (2015). Validity and Reliability of the Turkish Version of the Smartphone Addiction Scale - Short Version Among University Students. Anatolian Journal of Psychiatry, 16 (special issue.1), 73-81.

Oskay, U. (2013). Yikanmak Istemeyen Cocuklar Olalim. Istanbul: Yapi Kredi Yayinlari.

Rice RE, Katz JE. Comparing internet and mobile phone use: Digital divides of use, adoption and dropouts. Telecommunications Policy. 2003;27(8- 9):597-623.

Samaha, M., Hawi, N.S. (2016). Relationships among smartphone addiction, stress, academic performance, and satisfaction with life. Computers in Human Behavior, 57, 321-325.

Shambare R, Rugimbana R, Zhowa T. Are mobile phones the 21st century addiction? African Journal of Business Management. 2012;6(2):573-77.

Turkyilmaz, M. (2012). The Effect of Information Communication Technologies Towards Reading Attitudes. Bilgi Dunyasi, 13(2), 477-493.

Zulkefly S, Baharudin R. Mobile phone use amongst students in a University in Malaysia: Its Correlates and Relationship to Psychological Health. European Journal of Scientific Research. 2009;37(2):206-18.

\section{Internet Sources:}

CNNTURK. "Türkiye kitap okuma oranında kaçıncı sırada?" (21.02.2017). Retrieved, 12.10.2017: https://www.cnnturk.com/video/turkiye/turkiye-kitap-okuma-oraninda-kacinci-sirada

Nestle Family Monitor (2003). Young People's Attitudes Towards Reading. Retrieved, 12.10.2017: https://www.ipsos.com/sites/default/files/migrations/en-uk/files/Assets/Docs/Publications/sri-nestleyoung-peoples-attitudes-towards-reading.pdf

Zhang, K.Z.K., Chen, C., K O Lee, M. (2014). Understanding the Role of Motives in Smartphone Addiction. PACIS $2014 \quad$ Proceedings. Retrieved, 12.10.2017: https://www.researchgate.net/publication/265250524 Understanding the Role of Motives in Sma rtphone Addiction 